\title{
ECONOMIC SANCTIONS AND INTERNATIONAL SECURITY *
}

Article I6 of the Covenant of the League of Nations provides for the severance of commercial, financial, and personal relations between a covenant-breaking State and the other member States. ${ }^{1}$ The proposed application of economic sanctions against a recalcitrant State represents the first step under international agreement whereby the employment of economic pressure is to become a means of maintaining the peace of the world. The control of this powerful weapon rests finally with the Council of the League and its application calls for the rendering of mutual assistance by the member States in accordance with such plans as the Council may deem feasible. Failure of a State to observe its obligations under Articles I2 to I7, inclusive, of the Covenant opens the way to a consideration by the Council of the issues involved. Should the offending power continue in an unyielding mood the League will ultimately set in motion the machinery for the application of economic pressure. ${ }^{2}$

*The security treaties recently signed at Locarno provide for Germany's entrance into the League of Nations and for German membership on the League Council. The signatory powers have accepted the view that the obligations which Germany shall assume under Article I6 of the Covenant are subject to the interpretation embodied in Article II of the Geneva Protocol. It is considered that Germany as a member of the Council will have every opportunity of protecting her special position if the problem of applying economic sanctions ever arose. The attitude of Great Britain or other leading powers towards the Protocol in no way affects their acceptance of the amendments or reservations attaching to Article I6. The machinery of applying economic measures, as outlined in this study, has been set up by the League itself. The Protocol and the security treaties simply incorporate principles which the League is prepared to put into effect.

${ }^{1}$ The original Article 16 also provided that the Council "recommend to the several Governments concerned what effective military, naval or air force the members of the League shall severally contribute to the armed forces to be used to protect the covenants of the League." The member States also agree to co-operate in applying financial and economic measures and to allow passage for the forces of any members thus co-operating in protecting the League covenants. Any member violating any such covenants may be declared no longer a member of the League.

${ }^{2}$ By Articles 12, I3 and I5 of the League Covenant the members agree to submit their disputes to arbitration or to inquiry by the Council. They agree not to go to war within three months after an award by the arbitrators or a report by the Council has been made as well as to carry out the award in good faith. They commit themselves not to go to war with any member complying with such award or decision. The Council shall, in case further steps are 
The Protocol for the Pacific Settlement of International Disputes, approved by the League Assembly in September, 1924, has underlying it the principle of compulsory arbitration and rests upon the recognition of economic, naval, and military sanctions. It strengthens Article I6 of the Covenant by placing military force directly behind the economic sanctions. It increases the Article's significance by making it impossible for a nation to enter upon aggressive war without inviting upon itself the application of the economic blockade. When all the instrumentalities for arbitration and peaceful settlement of a dispute between the contending parties have been exhausted, the Council "shall call upon the signatory States to apply forthwith against the aggressor the sanctions provided by Article II" of the Protocol. ${ }^{3}$ Such signatory States become entitled thereupon to exercise the rights of belligerents and their obligations with regard to the sanctions of Article I6 of the Covenant immediately become operative.

The obligations which the members of the League accepted under the terms of Article I6 were the subject of much discussion during the first two years of the League's operation. Early in I92I the Council appointed an International Blockade Commission whose recommendations constituted the basis of a series of resolutions which the Assembly formally adopted in October of that year. ${ }^{4}$ The Sixth Committee of the First Assembly had in the meantime undertaken a preliminary study of the problems connected with the application of economic measures. The conclusions of the Commission passed under the final consideration of the Assembly late in I92I and were formally adopted

necessary to check any of the parties to the dispute, publish a report containing a statement of the facts in the dispute and of its conclusions. In case the report disputants are free to take whatever individual action each may consider neces-
sary. If the question at issue is by international sary. If the question at issue is by international law solely within the domestic jurisdiction of the parties the Council shall, by Article I5, not make a recommendation as to its settlement. If, however, any member resorts to war in violation of the obligations assumed under these provisions, Article to whall at
once become applicable.

${ }^{3}$ Should the two parties to the dispute be deemed aggressors the economic and financial sanctions shall be applied to both.

Official Journal, Specialist Supplement, No. 6 (Oct., I92I), 24-26. See also LeVERMORE, SECOND YeARbook of the League of Nations, I62-I64. 
in the nature of nineteen interpretative and qualifying resolutions. These rules of procedure are intended to guide the League in prescribing the course of action should any case calling for economic sanctions arise.

International law contains no precedents for the application of such far-reaching measures against a State as are contemplated in Article $16 .{ }^{5}$ The assumption on which the efficacy of the economic boycott rests, viz., the growing economic interdependence of the nations of the world, itself suggests that there exist no traditional bases for its application. As to the effective results of commercial and financial pressure, we find ample testimony in the economic desert which the close of the war revealed in Central Europe. The Paris Resolutions of IgI6 and the contemporaneous German efforts looking toward a post-war economic union in "middle Europe" indicated that the belligerents clearly realised the role which the possession or effective control of essential raw materials would be bound to play in the international relations of the future.

The sanctions of Article $16^{\circ}$ are, of course, only a part of a new and formal plan of international organization. Before the end of I9I4 the far-reaching effect of war under modern conditions was painfully evident and in all the great commercial countries there appeared responsible bodies of citizens with plans for a world organisation which should make for international understanding and guard against war. Practically all seriously proposed schemes provided for economic sanctions. ${ }^{6}$

The First Assembly of the League of Nations, late in I920, turned seriously to the examination of certain fundamental features of the Covenant. The application of Article 16, together with the problems relating to mandates and disarmament, was assigned to the Sixth Committee, where a subcommittee under

${ }^{5}$ Pacific blockade represents the nearest approach to the application of pressure against States against which it is not considered necessary or desirable to open hostilities. Pacific blockade has, however, been generally limited to action by greater against smaller powers. It is not a close precedent for the comprehensive measures whose international application a recalcitrant power, great or small, invites upon itself by violating its obligations under the Protocol.

- See, for example, the plan of the League to Enforce Peace in World Peace Foundation, Pamphlet Series, VI, No. 6. For outline of English, French and German proposals see DugGan, League of Naxions, Chapter VII. 
the chairmanship of Lord Robert (now Viscount) Cecil prepared a preliminary report. The problem proved an intricate one and when the International Blockade Commission met in August, I92I, all the member States were requested to have their Government submit any information, data, or suggestions which they could collect from their experiences in enforcing the blockade against Germany during the war. "In approaching the problem of Article 16," the Third Committee of the Second Assembly reported, "we are bound to recognise that this Article has established a new system of law which, by reason of its very novelty, raises many questions and gives rise to many difficulties of interpretation." 7

Factors of geography, differences in resources, and inequalities in naval power, immediately lay at the basis of differences of opinion which became articulate when the Assembly met in September, I920. The absence of two of the most nearly selfsustaining States added to the difficulties. The Covenant did not answer the question, Who is to judge when a State may rightfully apply pressure against a neighbor? Again, Shall all member States apply economic measures simultaneously and with equal force? What powers, if any, are to apply an effective naval blockade in case the law-breaking power has an unguarded sea-coast?. Does the unilateral action of the aggressor create a state of war? What duties are to be imposed upon non-member States in case one or more should border on the Covenant-breaking power? What steps should be taken against a non-member in case it refuses to accept the obligations of the League Covenant? These and other questions of a similar. nature clearly suggested the comprehensive scope of those clauses of the Covenant which pertain to economic sanctions.

On August 3, I920, Signor Tittoni, of Italy, read a report on the "economic weapon" at the San Sebastian meeting of the Council in which he briefly summarised the implications of economic penalties and recommended that immediate steps be taken to formulate a set of rules to guide the League and the

"Second Assembly Records, Plenary Meetings, 402. 
individual member States in assuming their obligations under Article 16. ${ }^{8}$ The Council thereupon passed a resolution requesting the Assembly to consider, at its first session, "the measures necessary to ensure the application of Article I6." Inasmuch as the Scandinavian countries had already submitted an amendment ${ }^{9}$ to paragraph one of this Article it was not without significance that the members of Lord Cecil's subcommittee were the representatives of smaller powers and were in sympathy with the reservation proposed by the former "North-European neutrals."

On December 10, I920, the Assembly formally recommended that the Council appoint an International Blockade Commission, to consist of not more than eight members, "to examine the application of Article 16 " and to report its conclusions to the Council. ${ }^{10}$ After the final formulation of the Nineteen Resolutions by the Assembly a year later, the Secretary-General submitted them to the members for acceptance. Certain amendments to Article I6 which are awaiting ratification at the present time may induce changes in these rules, but "so long as the

\footnotetext{
${ }^{8}$ Assembly Document No. 20 (I0/597I/I6), 3; First Assembly Records, Meetings of Committees, II, 332-334.

- The amendment proposed by the Scandanavian countries early in I92I was an extension of paragraph one: "At the request of a member for whom the application of the above provisions might entail serious danger the Council may authorise the member to maintain intercourse in such measure as the Council may decide, with the Covenant-breaking State." First Assembly Records, Meetings of Committees, Vol. I, 68-7I. The viewpoint of the Scandanavian powers was well expressed by the Swedish Government: "It can indeed be imagined that . . the Great Power . . might be tempted to occupy the territory of the smaller Power, so as to protect the very important economic interests which, as a result of the blockade, would be at stake. For this reason the Swedish Government is of the opinion that it would be desirable in cases of this nature to leave to the Council the option of modifying in some measure the obligation upon a member of the League to take part in the blockade." 72. Besides South Africa, represented by Lord Cecil, the countries represented on the Sub-Committee were Sweden, Jugoslavia, Roumania, and Switzerland.

${ }^{10}$ Official Journal, 2d year, No. 2 (March-April, I92I), II7. The powers represented on the Blockade Commission were Cuba, Spain, Norway, Switzerland, and the four permanent members of the Council-Great Britain, France, Italy and Japan. The Secretary-General of the League addressed two circular letters dated February 25, and March 2I, I92I, to the League members requesting that they submit, for the use of the Commission any explanatory statements regarding their interpretation of Articles I2-I7 of the Covenant and any statements concerning the blockade of Germany during the war which might be useful. Official Journal, Nos. 5-6 (July-August, I92r), 43r.
} 
amendments have not been put in force in the form required by the Covenant" these proposals shall "constitute rules for guidance" in the application of the economic blockade. ${ }^{11}$

Diplomatic relations are to be limited in the beginning to the withdrawal of the heads of missions. ${ }^{12}$ Consular relations shall continue as long as possible ${ }^{13}$ and humanitarian work is not to be disturbed by the severance of commercial relations. ${ }^{14}$ In accordance with the spirit of the Covenant "the League of Nations should attempt, at least at the outset, to avoid war, and to restore peace by economic pressure." 15 Lord Cecil pointed out the necessity of distinguishing between an act of war and a state of war and maintained that the unilateral action of the defaulting State was by itself insufficient to create a state of war. He expressed the view that the action of the defaulter merely entitled the other States to resort to acts of war or to declare themselves in a state of war with the Covenant-breaking State. This view finally prevailed. ${ }^{16}$

Whose duty is it to decide whether a breach of the Covenant has taken place? On this point opinion in the Assembly was divided. A memorandum prepared by the Secretary-General affirmed that "a primary responsibility rests upon each Government to take action so far as its own nationals and own national machinery are concerned, arrangements being made by each of them separately and not by a single international authority." 17 Signor Schanzer, of Italy, and Dr. Benes, of Czecho-Slovakia, among others, upheld the contention that it would be dangerous for each State to decide for itself when to institute a blockade. Dr. Benes frankly expressed the view that the Council alone

\footnotetext{
"Resolution Number One.

${ }^{12}$ Resolution Number Eleven.

${ }^{13}$ Resolution Number Twelve.

${ }^{1 *}$ Resolution Number Sixteen.

${ }^{15}$ Resolution Number Three.

${ }^{16}$ Second Assembly Records, Meetings of Committees, 287. See also M. de Aguero (Cuba) on the distinction" between a "state of war" and an act of war, 288. M. Huber (Switzerland) received general support in his contention that Article 16 could not possibly be interpreted as automatically creating a state of war for, he maintained, the League of Nations should never create a state of
} war, 289 .

${ }^{17}$ First Assembly Records, Meetings of Committees, II, 335. 
had authority to decide whether a breach had taken place and to order the members of the League to resort to economic penalties. ${ }^{18}$ The Dutch representative held out strongly for freedom of judgment on the part of the individual States. ${ }^{19} \mathrm{He}$ was supported by Mr. Fisher, of Great Britain, and by Lord Cecil. The latter expressed the opinion that, when once the Council-or the Assembly if in session-had informed the members that the obligations to act had arisen each State was morally bound to act in close co-operation with the rest in order to produce the most effective blockade. ${ }^{20} \mathrm{M}$. Oka, the Japanese representative, maintained that the right of each State as a sovereign power to make its own decisions ought to be safeguarded but that it is, at the same time, essential that executive decisions be centralised in the Council in order to compel unity of action. ${ }^{21}$ It was definitely agreed that each member of the League should decide for itself whether a breach of the Covenant had been committed. At the same time, it was to be understood that the fulfilment of their duties under Article 16 is required from members of the League by the express terms of the Covenant and that they cannot neglect them without breach of their treaty obligations. ${ }^{22}$

The Assembly made it clear that the duties of the Council in the enforcement of the economic blockade were confined to making recommendations. The final decision regarding the moment when a State shall apply sanctions and by what means such sanctions are to be enforced lie with the individual member States. Their obligations under the Covenant commit them to mutual co-operation but they remain legally free to determine their own line of action. The Assembly formally admitted that it is impossible to decide in advance and in detail the various measures that should apply in a particular case. The Council was, however, to recommend to the League members a plan for joint action whenever a case should arise. ${ }^{23}$

\footnotetext{
${ }^{15}$ Ibid., 266.

${ }^{18}$ Ibid., 262.

${ }^{2}$ Ibid., 265.

${ }^{21}$ Second Assembly Records, Meetings of Committees, I, 292.

= Resolution Number Four.

${ }^{2}$ Resolution Number Ten.
} 
While the decisions of the Council under Article 16 are not legally binding and do not constitute executive action this body remains, nevertheless, in control of the machinery which exists for the enforcement of punitive measures. All cases of breach of the Covenant are to be referred to the Council. Upon notice from a League member or from the Secretary-General that a breach has occurred, or that a breach threatens, the Council shall meet as soon as possible. ${ }^{24}$ The Council then summons representatives of the parties to the conflict and of all States which are either neighbors of the defaulting State or which, because of their economic relations with such State, should be consulted in order to assure the greatest degree of co-operation. If the Council is of the opinion that a State has been guilty of a breach of the Covenant the minutes of the meeting at which such opinion was reached shall at once be sent to all the League members. At the same time there shall be submitted a statement of reasons for action and a recommendation regarding the exact nature of such action. The Council may, if it so desires, be assisted by a technical committee to convene in continuous session as soon as the action decided upon is taken. ${ }^{25}$

The Council recommends the date on which the enforcement of the economic measures are to commence. The final decision vetoed the Blockade Commission's suggestion that the Council

"In the summer of I92I when the military forces of the Serb-CroatSlovene State crossed the Albanian frontier, Lloyd George, then Prime Minister of Great Britain, sent a telegram to the Secretary-General advising him to "take immediate steps to summon a meeting of the Council to consider the situation and to agree upon measures to be taken under Article I6 in the event of the Serb-Croat-Slovene Government refusing or delaying to execute their obligations under the Covenant." Monthly Summary of the League of Nations, Vol. I, No. 8 (December, I92I), I75.

23 In addition to the Serbian-Albanian crisis of Igar two other incidents created situations which threatened to bring Article 16 into operation. Early in I923 M. Viviani, then President of the Council, seryed notice on Lithuania that Article 16 would be applied against her in case her Government continued to violate the armistice agreement of October 7, I920, with Poland. See Monthly Summary of the League of Nations, Vol. III, No. 3 (March, I923), 23. See also, NEW YoRk Trmes, February 4, I923. The other crisis which, at first, promised to call for action under Article I6 was the Corfu affair between Greece and Italy in August, I923. The peaceful settlement, effected through the Council of Ambassadors, however, avoided the necessity of direct action by the Council. On the nature of the settlement see A. L. LOWEL, THE CouNCIL of THE LEague of Nations and CORFu, in World Peace Foundation, Vol. VI, No. 3. 
"fix" the date. Neighboring States are thus not prevented from taking special measures at once should their interests be threatened. ${ }^{26}$

The original text of Article I6 provided that member States sever relations between "their nationals and the nationals of the Covenant-breaking . State." This provision was in accordance with British and French practices inaugurated against Germany early in the war. A French decree of September 27, I9I4, had made nationality the test of enemy trade and was followed a year later by the British Blacklists. Under modern conditions the easy means of shifting credits and the growth of contraband lists allow enemy nationals to carry on economic war from neutral territory. The principle that nationality rather than residence should constitute the accepted criterion in the application of measures against enemy trade immediately invited attack from certain quarters. M. Motta, of Switzerland, declared that the severance of economic intercourse must be between territories, not between persons. In Switzerland, where fifteen out of every hundred of the population are foreigners, the application of Article I6, as originally phrased, would result in economic war within the country. The Assembly accepted the Swiss viewpoint and passed a resolution which provided that "for the purposes of the severance of relations between persons belonging to the Covenant-breaking State and persons belonging to other States members of the League, the test shall be residence and not nationality." 27 The Assembly at the same session adopted an amendment to Article 16 which substituted "persons residing in" for "nationals." 28

The French representatives remained firm in their opinion that the original provisions were essential to the prohibition of enemy trade. M. Reynauld's powerful plea led to an agreement by the Assembly which provided that both residence and nationality should form the basis for prohibiting trade with a default-

${ }^{2}$ Second Assembly Records, Plenary Meetings, 440.

${ }^{2}$ Resolution Number Thirteen.

= Handbook of the League of Nations, 1920-1924, World Peace Foundation, Pamphlet Series, Vol. VII, Nos. 3-4, 255 . 
ing State. ${ }^{29}$ Late in its second session the Assembly adopted an amendment embodying the new proposals. The members were slow in ratifying, not because of general disapproval, but because it was not clear what limitations existed to the employment of economic force under the widening scope of Article r6. In order to remove these uncertainties Great Britain proposed an amendment of a more definite and detailed nature which the Assembly adopted at its fifth session in September, I924. This amendment is at present before the members for ratification. ${ }^{30}$

On November 27, 1920, Lord Robert Cecil read a statement before the Committee on Armaments, Mandates and the Economic Weapon in which he suggested that the International Blockade Commission work out a practicable plan which should offer protection for countries which, by virtue of their geography and economic position, would incur grave dangers by enforcing a blockade against a neighboring State. Switzerland, Holland and the Scandinavian "neutrals" experienced these disadvantages during the Great War. The Assembly accepted the argument that "it may be necessary to recommend the execution of special measures by certain States." 31 The Blockade Commission had reported somewhat vaguely that the Council should undertake to grant exemptions to certain powers, thereby allowing their respective Governments to derogate from the steps involved in the application of Article I6.32 The Assembly, however, refused to accept any reservations which allowed certain States to issue

\footnotetext{
${ }^{29}$ Second Assembly Records, Plenary Meetings, 808-8Io.

${ }^{20}$ The amended text reads as follows: "Should any Member of the League resort to war in disregard of its covenants under Articles XII, XIII, or XV, it shall ipso facto be deemed to have committed an act of war against all other Members of the League, which hereby undertake immediately to subject it to the severance of all trade or financial relations and to prohibit all intercourse at least between persons resident within their territories and persons resident within the territory of the covenant-breaking State and if they deem it expedient, also between their nationals and the nationals of the covenant-breaking State, and to prevent all financial, commercial, or personal intercourse at least between persons resident within the territory of that State and persons resident within the territory of any other State, whether a Member of the League or not, and if they deem it expedient, also between the nationals of that State and the nationals of any other State whether a Member of the League or not." Monthly Summary of the League of Nations, Vol. IV, No. 9 (September, I924), I77.

"Resolution Number Nine.

${ }^{32}$ Document A.28.I92I.V.; C.288.I92r.V. 7.
} 
licenses, a process bound to open the flood-gates of exemptions. An amendment to the original draft resolution, offered by $M$. Poullet, of Belgium, introduced a cleverly devised scheme of "graduated" measures. This substitution provided that "if it is thought desirable to postpone; wholly or partially, in the case of certain States, the effective application of the economic sanctions laid down in Article I6 such postponement shall not be permitted except in so far as it is desirable for the success of the common plan of action, or reduces to a minimum the losses and embarrassments which may be entailed in the case of certain members of the League through the application of the sanction." 33

On February 27, I921, the Council instructed the SecretaryGeneral to communicate to the League members a request that they submit, for the use of the Blockade Commission, all available information which they could feel free to release relative to the means at their disposal for the enforcement of Article I6. ${ }^{34}$

The replies to the letter lacked agreement. In most countries the enforcement of the necessary measures is dependent upon special legislation. In France, for example, special legislative acts are necessary when the measures extend to prohibitions of importations and exportations of goods and the seizure of goods. The obligations cannot be carried out by executive decree except in regard to the prohibition of certain classes of goods. ${ }^{35}$ The Swedish Government is compelled to act in accordance with special legislation only when aiming to prohibit commercial transactions in the transport of merchandise between home ports and foreign ports. In exceptional circumstances it may issue import and export prohibitions and take general measures of control. The extent of immediate executive action in a particular case remains uncertain. ${ }^{36}$ The Swiss reply explained that the Government has the de facto control over almost

Resolution Number Nine.

"Official Journal, 2d year, No. 2 (March-April, I92I), II7.

${ }^{35}$ Official Journal, Nos. 5-6 (July-August, I92I), 433.

${ }^{\infty}$ The Swedish Government may also regulate all transport service and is empowered to suspend communications by rail between Sweden and other countries and to prohibit the conveyance of goods, passengers, or news to any particular country. 
all means of communication between Switzerland and foreign countries. No special difficulties could, therefore, arise in case the immediate suspension of such communications were ordered into effect. ${ }^{37}$ Finland assured the Commission that no previous consent of the Finish Parliament would be required to warrant immediate steps by the Government to fulfil the obligations under Article I6.38 The Dutch Government submitted a lengthy memorandum on the subject of the Queen's powers which showed that the validity of particular measures depends upon the nature of the circumstances and that the period of their validity is limited. Besides, there exist certain restrictions upon the application of executive measures. ${ }^{39}$

The Geneva Protocol for the Pacific Settlement of International Disputes not only' adopts the sanctions of Article I6 but it adds "teeth" to their structure. Dr. Benes, reporting for the Third Committee of the Fifth Assembly in September, I924, commented on the nature of the sanctions under the Protocol in these significant phrases:

"It is true that no burden has been imposed on States beyond the sanctions already provided for in the Covenant. But, at present a State seeking to elude the obligations of the Covenant can reckon on two means of escape-

(I) The Council's recommendations need not be followed.

(2) The Council may fail to obtain unanimity, making possible any declaration of aggression, so that no obligation to apply military sanctions will be imposed and everyone will remain free to act as he chooses.

"We have abandoned the above system and both these loopholes are now closed." 40

${ }^{37}$ Ibid., 434

${ }^{38}$ Ibid., 435 .

${ }^{30}$ Document A, 32/192I (C. B. 4a), 30-3r.

* Arbitration, Security and Reduction of Armaments, Documents and Proceedings of the Fifth Assembly, Information Section, League of Nations Secretariat, p. 65. See also Monthly Summary of the League of Nations, Supplement, October, I924, 29. 
The obligation of the signatory States to apply sanctions now arise directly from the decision of the Council. Each signatory is bound "in resistance to an act of aggression, to collaborate loyally and effectively in applying the sanctions in accordance with its geographical situation and its particular situation as regards armaments." The sanctions provided for in Article 16 of the Covenant are fundamentally economic, but as interpreted and amplified in the Protocol they are "not merely economic but also military." 41

Article I7 of the Covenant invites a non-member State to accept the obligations of membership in case of a dispute between it and a member State. Should the non-member refuse and resort to acts of war the provisions of Article I6 become applicable. The International Blockade Commission passed rather lightly over this question. With States such as Russia, Germany, and the United States outside the League the best that the members could hope for was passive co-operation from such States. ${ }^{42}$ Under the Protocol if a non-member of the Covenant or nonsignatory of the Protocol refuses to conform to the pacific procedure of the instrument and resorts to war the sanctions of Article 16 of the Covenant, as interpreted and amplified by the provisions of the Protocol, will be applied to it. ${ }^{43}$ That the enforcement of these provisions under present conditions is apparently hopeless in certain possible cases was given by Great Britain as one of the objections to the Protocol. On March I2, 1925, Mr. Austen Chamberlain, speaking for the British Empire, told the Council in session at Geneva that Great Britain could not ratify the arbitration and security pact. He declared that "it is

1I Ibid., 78. M. Politis in Assembly debate.

- Resolution Number Seventeen. See also Second Assembly Records, Meetings of Committees, I, 292. In this connection the revised Lodge Resolutions presented by the Foreign Relations Committee to the United States Senate November 6, I9I9, are of interest. Number I2 read: "The United States reserves the right to permit, in its discretion, the nationals of a Covenantbreaking State, as defined in Article I6 of the Covenant of the League of Nations, residing within the United States or in countries other than that violating said Article 16 , to continue their commercial, financial, and personal relations with the nations of the United States." Cong. Record, Vol. 58, Part 8. 66th Cong., Ist sess., 8023 .

4Article I6 (of the Protocol). 
most unwise to add to the liabilities already incurred without taking stock of the degree to which the machinery of the Covenant has been already weakened by the non-membership of certain great States." 44

Article II of the Protocol enjoins the signatories to assume the obligations of loyal and effective co-operation in resisting any act of aggression. Geographical position and relative naval and military strength are to be taken into account by the Council in its recommendations. The Nineteen Resolutions, provisionally in force, adopt this principle. It follows logically that should it become necessary to enforce a naval blockade against an aggressor the burden should fall upon the leading naval powers in proportion to their relative naval strength and according to their proximity to the scene of possible war. ${ }^{45}$ The provisions of Article II of the Protocol have raised the question in England regarding the use of the British fleet in the settlement of future European outbursts calling for belligerent action. The Protocol here represents the emergence of a new conception of international law which runs counter to the traditional view of British naval supremacy. European statesmen must find a means of adjusting this new conception to those new conditions which arise from a growing interdependence, economic and political, among the nations of the world.

University of Pennsylvania,

Amos E. Taylor. Philadelphia, $P a$.

\footnotetext{
4 Extract No. 29 from the Official Journal, April I925, 2.

s Resolution Number Eighteen provides for the application of a naval blockade in certain instances.
} 